\title{
Bachelor of Science in Nursing
}

National Cancer Institute

\section{Source}

National Cancer Institute. Bachelor of Science in Nursing. NCI Thesaurus. Code C71350.

A four year academic degree in the science and principles of nursing, granted by a tertiary education university or similarly accredited school. 